The distance from phase border, that is, from the boundary layer, of $2.2 M$ saccharose and $0.25 M$ saccharose with suspended nuclei to the bottom of tube was $1.5 \mathrm{~cm}$., and the time of centrifuging was $30 \mathrm{~min}$. at $30,000 \mathrm{~g}$ (as calculated for the bottom of tube). The diameter of the tube was $16 \mathrm{~mm}$. The last centrifuging was performed on a super-speed attachment of an MSE refrigerator centrifuge at $0-2^{\circ} \mathrm{C}$. The nuclear fraction appears as a light yellow precipitate. When this method is used special attention must be paid in order to attain suitable thickness of the layer of $2 \cdot 2 \mathrm{M}$ saccharose solution and also to the diameter of the tube.

The smear of the nuclear fraction suspended in $0.25 M$ saccharose showed no whole cells, and only few very small fragments of cells were observed. The appearance of the nuclei was like this in living cells. The nuclei have clearly visible nucleoli and normally distributed intranuclear constituents; this is evidence of their normal status. We did not observe any deformation or agglutination of nuclei prepared by this method.

Department of Tumour Biology,

T. WILCZOK

K. ChORAż̇Y

Institute of Oncology, Gliwice, Poland.

1 Alfrey, V. G., Mirsky, A. E., and Osawa, S., J. Gen. Physiol., 40, 451 (1957).

${ }^{2}$ Hogeboom, G. H., Schneider, W. C., and Stribich, M. J., J. Biol. Chem., 196, 111 (1952).

${ }^{3}$ Chauveau, L., Moulé, J., and Roulier, Ch., Exp. Cell. Res., 11, 317 (1956).

${ }^{4}$ Zbarskij, I. B., and Georgiew, G. P., Biochimia, 24, 192 (1959).

\section{Case of Apparent Resistance of Rattus norvegicus berkenhout to Anticoagulant Poisons}

Over a period of two months, a heavy rat population on a farm in the west of Scotland was treated with two anticoagulant poisons, 'Diphacinone' and 'Warfarin'. Although the treatments were properly conducted, and the rats ate the poison bait freely, little impression was made on the size of the population. There was no evidence of recruitment from outside, and the conclusion drawn was that this population was more than normally resistant to these anticoagulants. Cage tests on 28 animals trapped on the farm to confirm this gave the results shown in Table 1 .

\begin{tabular}{|c|c|c|c|c|}
\hline & Poison & $\begin{array}{l}\text { Concentration } \\
\text { (per cent) }\end{array}$ & $\begin{array}{l}\text { No. of } \\
\text { davs } \\
\text { feeding }\end{array}$ & Mortality \\
\hline Farm rats & $\begin{array}{l}\text { 'Diphacinone' } \\
\text { 'Warfarin' } \\
\text { Nil }\end{array}$ & $\begin{array}{l}0.0025 \\
0.005 \\
-\end{array}$ & $\begin{array}{l}5 \\
5 \\
\end{array}$ & $\begin{array}{l}2 / 9 \\
1 / 9 \\
0 / 10\end{array}$ \\
\hline Controls & 'Warfarin' & 0.005 & 5 & $12 / 15$ \\
\hline
\end{tabular}

The remaining 25 rats were further tested at the Ministry of Agriculture, Fisheries and Food laboratories at Tolworth with similar results. More work on the survivors and their progeny is in progress.

Department of Agriculture

C. Mary Boyle

and Fisheries for Scotland,

Rodent Control,

East Craigs,

Edinburgh, 12.

\section{Ophiuroids feeding on Phytoplankton}

ReCentuy, Nagabhushanam and Colman ${ }^{1}$ have described carrion-eating by some species of ophiuroids including Ophiocomina nigra (Abild.) and Ophiothrix fragilis (Abild.), from observations both in the laboratory and in the sea, a phenomenon which has been recorded previously 2,3 . The two species mentioned as well as Ophiopholis aculeata (L.) have, however, been reported to feed on a wide range of food from seston and plankton to bottom invertebrates ${ }^{2,3}$. In particular, Ophiothrix fragilis and Ophiopholis aculeata are considered to be mainly suspension feeders 4,5 (using strong ciliary currents ${ }^{6}$ in catching detritus), being also facultatively carnivorous. Of the species mentioned, Ophiocomina is anatomically well adapted for a carnivorous habit ${ }^{3}$. Nevertheless, all the species mentioned are considered to feed in essentially the same way 2,3 .

In order to evaluate the efficiency as suspension feeders of the three species mentioned, we have fed them with phytoplankton labelled with carbon-14. The animals were starved for 1-2 weeks. Two or three individuals of the same species were placed in each of a series of jars containing $400 \mathrm{ml}$. membrane-filtered sea water to which identical concentrations of carbon-14 labelled plankton algae (natural phytoplankton populations) were added. In every experiment mentioned, constant stirring in 'plunger jars'? prevented settling of phytoplankton. The animals were kept in the dark and at a constant temperature.

Two different substrata for the ophiuroids were used; stones and empty shells as one, and the octocoral Alcyonium digitatum $\mathbf{L}$. as the other. The latter was used because Ophiothrix is often found clinging to it, a phenomenon which is in accordance with the view that Ophiothrix is a reophile animal' ${ }^{8}$. After $18 \mathrm{hr}$. the radioactivity of the stomach contents of the ophiuroids was measured.

\begin{tabular}{|c|c|c|}
\hline \multirow[b]{2}{*}{ Species } & \multicolumn{2}{|c|}{ Substratum } \\
\hline & $\begin{array}{l}\text { Stones and } \\
\text { empty shells } \\
\text { (c./min.) }\end{array}$ & $\begin{array}{l}\text { Aleyonium } \\
\text { digitatum } \\
\text { (c./min.) }\end{array}$ \\
\hline Ophiothrix & 186 & 326 \\
\hline \multirow{3}{*}{ Ophiopholis } & 226 & 120 \\
\hline & 162 & 59 \\
\hline & 79 & $20 \cdot 3$ \\
\hline \multirow[t]{3}{*}{ Ophiocomina } & 0 & 0 \\
\hline & () & $0 \cdot 9$ \\
\hline & 0 & $1 \cdot 3$ \\
\hline Alcyonium & 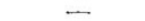 & 110 \\
\hline
\end{tabular}

On the dead substrates, no uptake of phytoplankton by Ophiocomina was found. The faint traces of radioactivity measured in specimens of Ophiocomina using Alcyonium as a substrate is a secondary phenomenon as the octocoral has a priori filtered the algae. Ophiocomina accordingly cannot be regarded as a sus. pension feeder, in contrast to the two other species which are extremely efficient suspension feeders, Ophiothrix being the superior one.

To measure the rate of removal of plankton algae by starved Ophiothrix and Ophiopholis, these species were fed with carbon-14 labelled strains of Sceletonema costatum. In both species three different concentrations of Sceletonema were used $(10: 5: 1)$, but the starting activity in the same concentrations was identical. In each of the $2 \times 3$ jars, three animals were placed in $400 \mathrm{ml}$. membrane-filtered sea water. The radioactivity in subsamples of $10 \mathrm{ml}$. water was measured at increasing time-intervals starting with $1 \mathrm{hr}$. 